\title{
Immobilisation of laccase on Eupergit supports and its application for the removal of endocrine disrupting chemicals in a packed-bed reactor
}

\author{
L. Lloret • F. Hollmann • G. Eibes • G. Feijoo • \\ M. T. Moreira $\cdot$ J. M. Lema
}

Received: 11 April 2011/Accepted: 14 October 2011/Published online: 29 October 2011

(C) Springer Science+Business Media B.V. 2011

\begin{abstract}
Laccase from Myceliophthora thermophila was covalently immobilised on Eupergit $\mathrm{C}$ and Eupergit C 250L yielding specific activities of up to 17 and $80 \mathrm{U} / \mathrm{g}$, respectively. Due to its superior activity, Eupergit $\mathrm{C} 250 \mathrm{~L}$ was chosen for further research. The somewhat lower catalytic efficiency (based on the ratio between the turnover number and the Michaelis constant, $\mathrm{k}_{\mathrm{cat}} / \mathrm{K}_{\mathrm{M}}$ ) of the immobilised enzyme in comparison with that of the free enzyme was balanced by its increased stability and broader operational window related to temperature and $\mathrm{pH}$. The feasibility of the immobilised laccase was tested by using a packed bed reactor (PBR) operating in consecutive cycles for the removal of Acid Green 27 dye as model substrate. High degrees of elimination were achieved $(88,79,69$ and $57 \%$ in 4 consecutive cycles), while the levels of adsorption on the support varied from 18 to $6 \%$, proving that dye removal took place mainly due to the action of the enzyme. Finally, a continuous PBR with the solid biocatalyst was applied for the treatment of a solution containing the following endocrine
\end{abstract}

L. Lloret · G. Eibes $(\bowtie) \cdot$ G. Feijoo ·

M. T. Moreira · J. M. Lema

Department of Chemical Engineering, School of Engineering, University of Santiago de Compostela, 15782 Santiago de Compostela, Spain

e-mail: gemma.eibes@usc.es

F. Hollmann

Department of Biotechnology, Delft University of

Technology, 2628BL Delft, The Netherlands disrupting chemicals: estrone (E1), 17 $\beta$-estradiol (E2) and $17 \alpha$-ethinylestradiol (EE2). At steady-state operation, E1 was degraded by $65 \%$ and E2 and EE2 were removed up to $80 \%$ and only limited adsorption of these compounds on the support, between 12 and $22 \%$, was detected. In addition, a $79 \%$ decrease in estrogenic activity was detected in the effluent of the enzymatic reactor while only $14 \%$ was attained by inactivated laccase.

Keywords Estrone $17 \beta$-estradiol · $17 \alpha$-ethinylestradiol $\cdot$ Laccase $\cdot$ Covalent immobilisation $\cdot$ Eupergit

\section{Introduction}

Estrogenic compounds, frequently present in personal care products (PCPs), are either known or suspected endocrine disrupting chemicals (EDCs) (Sei et al. 2008; Ternes et al. 1999). These compounds are environmental pollutants that may cause dramatic environmental effects such as the feminisation of entire fish populations in contaminated streams even in trace concentrations (Auriol et al. 2006; Blánquez and Guieysse 2008). EDCs have been detected in wastewater treatment plants (WWTPs), rivers, groundwaters and landfill leachates at concentrations ranging from nanograms to micrograms per litre (Carballa et al. 2005; Joss et al. 2006). Other studies reported that natural steroid estrogens (e.g. estrone and 
$17 \beta$-estradiol) and synthetic steroid estrogen $(17 \alpha-$ ethinylestradiol) are the major contributors to the estrogenic activity detected in WWTP effluents (Leusch et al. 2005). Moreover, steroid estrogens have been found to be biologically active at concentrations as low as $0.1 \mathrm{ng} / \mathrm{l}$ (Auriol et al. 2006).

The degradation of this type of compounds is still an important ecological challenge since conventional physicochemical or biological treatment can only attain partial degradation while advanced oxidation processes such as UV exposure or ozonation render variable degradation yields (Esplugas et al. 2007). Additionally, these recent processes (e.g. chemical oxidation and adsorption on activated supports) usually present a number of disadvantages, such as high costs, prolonged detoxification periods and production of toxic residues (Auriol et al. 2006; Kim and Nicell 2006). A biological alternative may be based on the use of white rot fungi. These microorganisms have been reported to degrade a wide range of xenobiotics by the action of their oxidative enzymes, e.g. manganese peroxidase, lignin peroxidase, versatile peroxidase or laccase (Durán and Esposito 2000; Kim and Nicell 2006).

Laccase (E.C.1.10.3.2., benzenediol: oxygen oxidoreductase) is a multi-copper protein which is able to oxidise phenolic substrates by reducing molecular oxygen to water (Wesenberg et al. 2003). This enzyme was reported to be a potential catalyst for the biodegradation of recalcitrant compounds: dyes, aromatic hydrocarbons compounds, olive oil mill wastewater and pulp delignification (Camarero et al. 2007; Yamak et al. 2009). In recent years, several research groups have explored the ability of free fungal laccases to remove a wide range of hormones: genistein, estrone, $17 \beta$-estradiol, estriol, and $17 \alpha$-ethinylestradiol (Auriol et al. 2008; Nicotra et al. 2004; Tamagawa et al. 2006; Lloret et al. 2010). Crude and purified laccase from Trametes versicolor and Trametes villosa were used to degrade bisphenol A (Kim and Nicell 2006) and nonylphenol (Tsutsumi et al. 2001).

The advantages of laccases for environmental applications are their broad substrate specificity and the use of oxygen, a non-limited electron acceptor (Berrio et al. 2007). However, although high degradation levels were attained in those previous studies with free laccase, its use in wastewater treatment may be limited due to the potential inactivation of the soluble enzyme in presence of some inhibitor compounds, extreme $\mathrm{pH}$ values or high temperatures. In order to overcome these limitations and provide steady systems, different methods (e.g. the use of stabilising additives, derivatisation, chemical modification of protein structure and immobilisation) could be applied (Illanes 1999). Immobilisation is the most commonly used method for enzyme stabilisation, because it provides many other benefits, such as the physical separation from the reaction medium, the reduction of enzyme replacement and the potential reuse of the catalyst (Kunamneni et al. 2008; Osma et al. 2010). Furthermore, immobilisation may shift the enzyme properties such as the kinetic parameters and the optimum values of $\mathrm{pH}$ and temperature. It may also strengthen the protein structure (Cabana et al. 2009; Durán et al. 2002).

Enzyme immobilisation by covalent binding onto a support has the advantage that the enzyme is tightly fixed, which minimizes the leaching of the enzyme from the support. Moreover, the formation of multiple covalent bonds between the enzyme and the support reduces conformational flexibility and thermal vibrations, thus preventing protein unfolding and denaturation (Hanefeld et al. 2009). The application of covalent immobilisation techniques considers two different possibilities: either the use of inert carriers which can be properly activated or even the use of active supports commercially available. Among the latter, Eupergit carriers have been reported to be effective supports for immobilisation of laccase (Hublik and Schinner 2000; Katchalski-Katzir and Kraemer 2000; Knezevic et al. 2006; Russo et al. 2008). Eupergit supports (epoxy-activated acrylic polymers) have been developed between 1974 and 1980 by Röhm, Darmstadt, Germany. The carriers are very stable and have several good chemical and mechanical properties, being considered suitable for covalent immobilisation of enzymes for industrial applications (Kraemer et al. 1985).

Laccase, covalently immobilised on various supports, has been evaluated for the treatment of pollutants such as phenols and dyes (D'Annibale et al. 2000; Durán et al. 2002; Kunamneni et al. 2008; Russo et al. 2008). However, to our knowledge, immobilised laccases on Eupergit supports have not yet been evaluated for the oxidative degradation of endocrine disruptor chemicals (EDCs), specifically, estrone, $17 \beta$-estradiol or $17 \alpha$-ethinylestradiol.

The main purpose of this study was to evaluate the ability of laccase from Myceliophthora thermophila 
immobilised on Eupergit to oxidize EDCs in a continuous packed-bed reactor. To attain this goal, specific objectives were proposed: (i) immobilisation of laccase on two epoxy-activated acrylic polymers (Eupergit C and Eupergit C 250L) to select the support with the highest immobilisation efficiency; (ii) characterisation of the free and immobilised laccases (stability at different $\mathrm{pH}$ and temperature, exposure to inactivating agents, kinetic parameters, reusability of immobilised enzyme and storage stability); (iii) development and operation of a packed bed reactor for the removal of a synthetic dye as a model compound and the targeted EDCs: estrone, $17 \beta$-estradiol and $17 \alpha-$ ethinylestradiol.

\section{Materials and methods}

Chemical reagents and enzyme

The dye Acid Green 27 (AG27, purity 65\%) and the endocrine disrupting chemicals (EDCs, $\geq 99 \%$ ): estrone (E1), $17 \beta$-estradiol (E2) and $17 \alpha$-ethinylestradiol (EE2) were obtained from Sigma-Aldrich (USA). A stock solution $(2,000 \mathrm{mg} / \mathrm{l})$ of the EDCs was prepared in methanol for its use in the removal experiments. 2,2'azinobis-(3-ethylbenzothiazoline-6-sulfonate)

(ABTS, $\geq 99 \%$ ) was supplied by Fluka (USA). All solvents were HPLC grade (Sigma-Aldrich, Germany). Epoxy-activated acrylic beads, Eupergit $\mathrm{C}$ and Eupergit C 250L, were purchased from Rohm GmbH (Germany).

Commercial laccase (Novozym 51003) from Myceliophthora thermophila was supplied by Novozymes (Denmark). This enzyme (molecular weight of $56,000 \mathrm{Da}$ ) was produced by submerged fermentation of a genetically modified Aspergillus sp.

Enzyme assay and protein estimation

Laccase activity was determined by monitoring the oxidation rate of $5 \mathrm{mM}$ ABTS to its cation radical $\left(\mathrm{ABTS}^{+}\right)$at $436 \mathrm{~nm}\left(\varepsilon_{436}=29,300 \mathrm{M}^{-1} \mathrm{~cm}^{-1}\right)$ in $0.1 \mathrm{M}$ sodium acetate buffer $(\mathrm{pH} 5)$ at $30^{\circ} \mathrm{C}$. One unit (U) of activity was defined as the amount of enzyme forming $1 \mu \mathrm{mol}$ of $\mathrm{ABTS}^{+}$per min. All spectrophotometric measurements were carried out on a Shimadzu UV-1603. Free laccase activity was expressed in $\mathrm{U} / \mathrm{l}$.
Immobilised laccase activity was assayed by incubating $20 \mathrm{mg} / \mathrm{ml}$ of biocatalyst preparation in a solution of $5 \mathrm{mM} \mathrm{ABTS}$ (in $0.1 \mathrm{M}$ phosphate buffer, $\mathrm{pH}$ 5) previously tempered at $30^{\circ} \mathrm{C}$ with continuous stirring at $150 \mathrm{rpm}$. The absorbance was monitored every minute over a $10 \mathrm{~min}$ period, by withdrawing $1 \mathrm{ml}$ of solution. After measurement, the solution was remixed with the immobilised laccase. Immobilised laccase activity was expressed in U/g biocatalyst.

Protein estimation was performed by the method of Pierce $^{\circledR} 660 \mathrm{~nm}$ Protein Assay Kit (Thermo Scientific), using bovine serum albumin as a standard. The quantity of protein bound to the supports was calculated from the difference between the protein loaded and that remaining in solution.

Laccase immobilisation on Eupergit supports

Laccase from Myceliophthora thermophila was immobilised on Eupergit supports by the method described by Katchalski-Katzir and Kraemer (2000). The enzyme was diluted in $0.1 \mathrm{M}$ phosphate buffer ( $\mathrm{pH} 7$ ), centrifuged and filtered to a final concentration of $90 \mathrm{mg} / \mathrm{ml}$ or $80 \mathrm{U} / \mathrm{ml}$. Different amounts of laccase: $11,22,55$, 110 and $220 \mathrm{mg}$ were mixed with $0.5 \mathrm{~g}$ of the carrier in $1 \mathrm{M}$ phosphate buffer ( $\mathrm{pH} 7$ ) in a final volume of $5 \mathrm{ml}$. The reaction mixture was vortexed for $2 \mathrm{~min}$ and then the suspension was incubated at room temperature $\left(24 \pm 2^{\circ} \mathrm{C}\right.$ ) with gentle shaking for $24 \mathrm{~h}$. The decrease of activity due to the operational conditions was determined by monitoring the activity of free laccase subjected to identical conditions. The biocatalyst was then filtered using a glass filter (Whatman), washed three times with $5 \mathrm{ml}$ of $0.1 \mathrm{M}$ phosphate buffer $(\mathrm{pH}$ 7 ), dried under vacuum and stored at $4{ }^{\circ} \mathrm{C}$. The immobilisation process was carried out at $\mathrm{pH} 7$ and room temperature since laccase from Myceliophthora thermophila retained $100 \%$ of initial activity under these conditions for at least $24 \mathrm{~h}$ (Lloret et al. 2010).

Bound protein was calculated as the difference between the protein content in the control and the protein remaining in the supernatant of the immobilised assay. The recovered activity was calculated as the ratio of the measured activity in the solid biocatalyst and the laccase activity theoretically immobilised onto the support. This theoretical activity was defined as the difference between the laccase activity in the controls and the remaining in the supernatant of the immobilised assay. 
Characterisation of free enzyme and immobilised laccase

\section{Optimum $\mathrm{pH}$ and $\mathrm{pH}$ stability}

The $\mathrm{pH}$ of maximum laccase activity (free and immobilised) was investigated using $50 \mu \mathrm{M}$ ABTS in a $0.1 \mathrm{M}$ citrate-phosphate-borate buffer ( $\mathrm{pH} 2-8)$. The relative activity was calculated as the ratio between the activity at each $\mathrm{pH}$ and the maximum attained.

The effect of the $\mathrm{pH}$ on the enzyme stability was studied by incubating laccase in $0.1 \mathrm{M}$ citrate-phosphate-borate buffer $(\mathrm{pH} \mathrm{2,} \mathrm{4,} 6$ and 8) at room temperature $\left(24^{\circ} \pm 2^{\circ} \mathrm{C}\right)$ during $24 \mathrm{~h}$. Samples were transferred to standard reaction mixtures in order to determine the laccase activity with $50 \mu \mathrm{M}$ ABTS. The residual activity was calculated referred to the value of the initial activity at each $\mathrm{pH}$.

\section{Optimum temperature and thermostability}

The effect of temperature $\left(20-80^{\circ} \mathrm{C}\right)$ on laccase activity was determined by measuring activity at the corresponding temperature under standard conditions. The relative activity was calculated as the ratio between the activity at each temperature and the maximum attained.

Thermal stability was determined by incubating enzymes in $0.1 \mathrm{M}$ phosphate buffer $(\mathrm{pH} 7)$ at selected temperatures: $20,40,50,60,70$ and $80^{\circ} \mathrm{C}$ for different periods. Samples were transferred to standard conditions to determine the laccase activity with $50 \mu \mathrm{M}$ ABTS at $30^{\circ} \mathrm{C}$.

\section{Stability against chemical inactivation}

The stability of laccase against different inactivating agents was tested using $1 \mathrm{~g}(10 \mathrm{U} / \mathrm{g})$ of support (immobilised enzyme) or $10 \mathrm{U}$ (free enzyme) in a volume of $3 \mathrm{ml}$. Enzyme inhibitors were added individually: $30 \mu \mathrm{M} \mathrm{NaN}, 10 \mu \mathrm{M} \mathrm{ZnCl}_{2}, 10 \mu \mathrm{M} \mathrm{CoCl}_{2}$, $10 \mu \mathrm{M} \mathrm{CaCl} 2,25 \%$ (v/v) methanol and $25 \%$ (v/v) acetone in $0.1 \mathrm{M}$ phosphate buffer $(\mathrm{pH} 7)$ at room temperature $\left(24 \pm 2^{\circ} \mathrm{C}\right)$. The incubations lasted for $30 \mathrm{~min}$ and then residual activities were measured by ABTS $(50 \mu \mathrm{M})$ standard assay.

\section{Determination of apparent kinetic parameters}

Apparent kinetic parameters of free and immobilised laccase were determined by measuring the laccase activity under standard conditions using ABTS as substrate in the range $25-1,500 \mu \mathrm{M}$. The parameter values were obtained by fitting the data to the Michaelis-Menten equation using a non-linear regression (Sigma Plot 7.0, SPSS Inc., USA).

\section{Reusability of the immobilised laccase}

The reusability of the immobilised laccase was investigated in repeated batch experiments using ABTS as a substrate. The enzyme was incubated with $50 \mu \mathrm{M}$ ABTS for $5 \mathrm{~h}$ (one cycle) in $0.1 \mathrm{M}$ phosphate buffer $(\mathrm{pH} 7)$ at room temperature $\left(24 \pm 2{ }^{\circ} \mathrm{C}\right)$. At the end of each oxidative cycle, the immobilised laccase was washed three times with $0.1 \mathrm{M}$ phosphate buffer $(\mathrm{pH}$ 7) and spectrophotometrically measured with $50 \mu \mathrm{M}$ ABTS. Thereafter, the procedure was repeated with a fresh solution of substrate. The activity measured in the first cycle was considered as the control $(100 \%)$ for the calculation of the remaining percent activity after each cycle.

\section{Storage stability}

The storage stabilities of free and immobilised laccase were investigated at $4^{\circ} \mathrm{C}$ and at room temperature $\left(24 \pm 2^{\circ} \mathrm{C}\right)$. Free enzyme was stored in a $0.1 \mathrm{M}$ phosphate buffer solution ( $\mathrm{pH} 7$ ), whereas immobilised laccase was stored in a closed glass tube. The residual activities were measured after 1,2 and 3 months by measuring the remaining laccase activity with $50 \mu \mathrm{M}$ ABTS under standard conditions.

Decolourisation of a model synthetic dye by immobilised laccase

A glass column (40 cm height, $2 \mathrm{~cm}$ internal diameter, $50 \mathrm{ml}$ of working volume) with immobilised laccase on Eupergit C 250L was used to remove the dye AG27 in a continuous operation of a packed bed reactor (PBR). Continuous operation conditions were the following: $10 \mathrm{~g}(9.7 \mathrm{U} / \mathrm{g})$ of the biocatalyst, dye flow rate of $1.5 \mathrm{ml} / \mathrm{min}$, hydraulic retention time of $30 \mathrm{~min}, 50 \mathrm{mg} / \mathrm{l}$ of the stock solution of the dye in the feeding tank, room temperature $\left(24 \pm 2^{\circ} \mathrm{C}\right)$ and $0.1 \mathrm{M}$ phosphate buffer 
$(\mathrm{pH} 7)$. After attaining the maximum decolourisation, the reactor was stopped and the decolourised solution drained. The packed bed was then washed with $20 \mathrm{ml}$ of $0.1 \mathrm{M}$ phosphate buffer ( $\mathrm{pH} 7$ ). The reactor was again filled with fresh dye solution and the process was then repeated for several cycles of identical duration. Samples from the reactor outlet were collected to determine the percentage of degradation. Before adding the biocatalyst and operating as described above, the reactor was fed with AG27 solution at a flow of $1.5 \mathrm{ml} / \mathrm{min}$ until the absorbance measured in samples collected from the outlet was similar to that of the inlet stream.

Moreover, aiming to evaluate the potential leaching of the immobilised enzyme into the reactor, samples from the liquid phase were withdrawn during each cycle. The absorbance of the collected samples was measured after 2, 5 and $15 \mathrm{~min}$ in order to determine if there was dye removal by the potentially leached laccase. To quantify any potential adsorption of the dye on the support, a column was run in parallel with the same amount of support and inactivated laccase (incubated at $105^{\circ} \mathrm{C}$ for $4 \mathrm{~h}$ ) under the same conditions applied for the PBR.

Removal of endocrine disrupting chemicals by immobilised laccase

A PBR was used for the continuous removal of selected EDCs (E1, E2 and EE2) from an aqueous solution. The operational conditions were identical to the ones mentioned previously with a concentration of the estrogens in the feeding tank of $5 \mathrm{mg} / \mathrm{l}$ of each EDC. The reactor was initially charged with the estrogens solution before adding the biocatalyst. The continuous operation was carried out for $8 \mathrm{~h}$ at room temperature $\left(24 \pm 2^{\circ} \mathrm{C}\right)$.

To quantify any potential adsorption for EDCs on the support with immobilised laccase, the same amount of Eupergit C 250L with previously inactivated laccase (incubated at $105^{\circ} \mathrm{C}$ for $4 \mathrm{~h}$ ) was used in the operation of the PBR. The potential leaching was evaluated by the same procedure described previously for the dye removal.

\section{Analyses of Acid Green 27 dye}

The efficiency of the enzymatic treatment was evaluated by monitoring the AG27 absorbance at its maximum absorption wavelength $(650 \mathrm{~nm})$ with a Shimadzu UV-1603 spectrophotometer. The percentage of decolourisation was calculated with respect to the initial measured absorbance.

High-performance liquid chromatography analyses

Determination of EDCs concentration was carried out through high performance liquid chromatography (HPLC) in a HP-1090 system equipped with a diode array detector and a Water Xterra-C18 column $(4.6 \times 150 \mathrm{~mm}$, particle size $5 \mu \mathrm{m})$. The operational conditions for the analysis were: $10 \mu \mathrm{l}$ injection volume, $\lambda 210 \mathrm{~nm}$, acetonitrile: phosphate buffer (50 mM, pH 4.5) as eluent in isocratic conditions of $40: 60 \%$ at a flow rate of $1 \mathrm{ml} / \mathrm{min}$.

Evaluation of estrogenic activity

The estrogenic activity was measured by the LYES (lyticase yeast estrogen screen-assay assisted by enzymatic digestion) assay previously described by Taboada-Puig et al. (2011), adapted from Schultis and Metzger (2004). The recombinant yeast Saccharomyces cerevisiae was kindly provided by the Laboratory of Microbial Ecology and Technology (Labmet, Ghent University, Belgium).

\section{Results and discussion}

Immobilisation of laccase

The effect of the amount of laccase on the immobilisation efficiency was evaluated in the range between 22 and $880 \mathrm{mg}$ of protein/g support (Table 1). Specific activities of up to 17 and $80 \mathrm{U} / g$ were measured for Eupergit $\mathrm{C}$ and Eupergit $\mathrm{C} 250 \mathrm{~L}$ respectively. It is evident that at increasing amounts of the enzyme, the activity recovery decreased probably due to the saturation of the support. For example, the increase in laccase load from 22 to $440 \mathrm{mg} / \mathrm{g}$ resulted in the decrease of activity recovery: from 36.1 to $21.1 \%$ for Eupergit $\mathrm{C}$ and more so, from 88.4 to $43.8 \%$, in the case of Eupergit C 250L. It is generally acknowledged that the immobilisation efficiency of enzymes on solid supports decreases when enzyme loading exceeds a certain value (Knezevic et al. 2006; Li et al. 2007). In 
Table 1 Recovery protein and activity in the immobilisation of $M$. thermophila laccase on Eupergit supports

\begin{tabular}{|c|c|c|c|c|c|c|}
\hline \multirow{2}{*}{$\begin{array}{l}\text { Added protein } \\
\text { (mg/g support) }\end{array}$} & \multicolumn{2}{|c|}{ Bound protein $^{\mathrm{a}}(\%)$} & \multicolumn{2}{|c|}{ Activity $^{\mathrm{b}}$ (U/g biocatalyst) } & \multicolumn{2}{|c|}{ Activity recovery ${ }^{\mathrm{c}}(\%)$} \\
\hline & Eupergit C & Eupergit C 250L & Eupergit $\mathrm{C}$ & Eupergit C 250L & Eupergit C & Eupergit C 250L \\
\hline 22 & $79.1 \pm 2.3$ & $99.3 \pm 2.8$ & $1.4 \pm 0.1$ & $9.7 \pm 0.5$ & $36.1 \pm 1.8$ & $88.4 \pm 4.1$ \\
\hline 44 & $75.9 \pm 5.1$ & $89.1 \pm 1.3$ & $2.4 \pm 0.1$ & $15.9 \pm 0.7$ & $28.4 \pm 1.1$ & $86.9 \pm 3.9$ \\
\hline 110 & $74.2 \pm 4.2$ & $84.2 \pm 0.5$ & $7.4 \pm 0.2$ & $24.3 \pm 0.3$ & $26.9 \pm 0.9$ & $50.9 \pm 2.5$ \\
\hline 220 & $61.3 \pm 0.2$ & $75.1 \pm 2.4$ & $10.1 \pm 0.3$ & $53.8 \pm 1.1$ & $23.9 \pm 2.1$ & $63.8 \pm 3.0$ \\
\hline 440 & $45.1 \pm 0.9$ & $61.9 \pm 4.6$ & $16.0 \pm 0.2$ & $72.9 \pm 1.1$ & $21.1 \pm 1.3$ & $43.8 \pm 2.1$ \\
\hline 880 & $43.8 \pm 1.1$ & $56.7 \pm 2.5$ & $17.1 \pm 0.3$ & $80.0 \pm 0.9$ & $19.2 \pm 1.1$ & $39.5 \pm 0.9$ \\
\hline
\end{tabular}

${ }^{a}$ The amount of immobilised protein was calculated from the difference between the protein in the control and protein remaining in the supernatant of immobilised assay

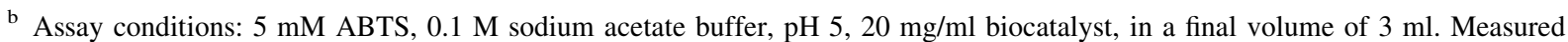
with immobilised biocatalyst over $10 \mathrm{~min}$ period

c Activity recovered was calculated as the ratio of measured activity to theoretic bound activity (difference between the laccase activity in the controls and the remaining in the supernatant of immobilised assay)

fact, it was observed that Eupergit carriers presented a saturation value of laccase of $440 \mathrm{mg}$ protein/g support. The obtained results were higher than those presented by Katchalski-Katzir and Kraemer (2000), who reported that the binding capacity of an enzyme is about $100 \mathrm{mg}$ protein/g Eupergit C. The same effect was observed regarding bound protein (79.1-43.8 and 88.4-43.8\% for Eupergit C and Eupergit C 250L in the range $22-440 \mathrm{mg}$ protein/g support).

Among both supports, Eupergit C 250L yielded the highest specific activity ( $80 \mathrm{U} / \mathrm{g}$ biocatalyst) and retained the highest amount of protein. Eupergit $\mathrm{C}$ $250 \mathrm{~L}$ presents lower concentration of reactive groups than Eupergit C, but larger pores, which may explain the higher immobilisation efficiency (Gómez de Segura et al. 2004; Berrio et al. 2007).

The activity yields related to bound protein and enzyme activity achieved in the present study were in the same range of magnitude than the ones previously reported for laccases immobilisation by covalent methods. For example, Kunamneni et al. (2008) immobilised laccase from Myceliophthora thermophila on Sepabeads EC-EP3 and Dilbeads NK supports with bound protein yields of 32.6 and $17.8 \%$, respectively. Berrio et al. (2007) attained levels of bound protein between 10.3-66.5 and 10.2-34.2\% for Pycnoporus coccineus laccase immobilised on Eupergit C and Eupergit C 250L, respectively.

Due to its superior activity, only laccase immobilised on Eupergit C 250L was used for further experiments: characterisation of the biocatalyst, decolourisation of a model dye and removal of endocrine disrupting chemicals.

Characterisation of free enzyme and immobilised laccase

\section{Optimum $\mathrm{pH}$ and $\mathrm{pH}$ stability}

The $\mathrm{pH}$-dependence of activity for free and immobilised laccases was analysed in a $\mathrm{pH}$ range from 2 to 8 , in a $0.1 \mathrm{M}$ citrate-phosphate-borate buffer. Both free and immobilised laccase showed that the optimal $\mathrm{pH}$ was 3 and the relative activity for the immobilised laccase was slightly higher $(10 \%)$ than that of free laccase in the range of $\mathrm{pH} 4-7$ (Fig. 1a).

The effect of the $\mathrm{pH}$ on the enzyme stability was studied by incubating both laccase formulations at $\mathrm{pH}$ 2, 4, 6 and 8 and room temperature for $24 \mathrm{~h}$. Figure $2 \mathrm{a}$, $\mathrm{c}$ depict the profiles of $\mathrm{pH}$ deactivation for free and immobilised laccase, respectively. While results were similar at neutral $\mathrm{pH}$ range, immobilised laccase presented higher stability at acid $\mathrm{pH}$. For example, free laccase was completely inactivated after $1 \mathrm{~h}$ of incubation at $\mathrm{pH} 2$, and retained only $15 \%$ of initial activity at $\mathrm{pH} 4$. However, the residual activity of immobilised laccase after $1 \mathrm{~h}$ amounted to 70 and $80 \%$ at $\mathrm{pH} 2$ and 4, respectively, and 10 and $30 \%$ of the initial activity after $24 \mathrm{~h}$.

Alptekin et al. (2010) reported that the multiplecovalent bonding of laccase to the resin resulting in more rigid enzyme less prone to $\mathrm{pH}$-induced 

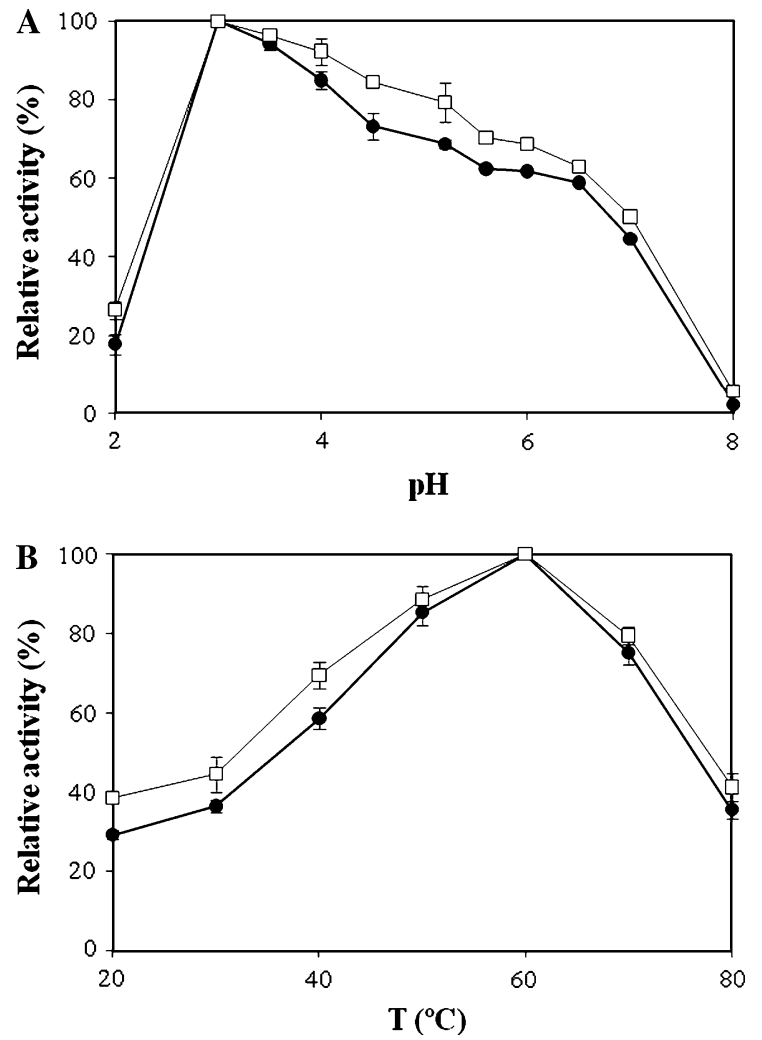

Fig. 1 Effect of $\mathrm{pH}$ (a) and temperature (b) on free (filled circle) and immobilised laccase on Eupergit C 250L (square). $\mathrm{pH}(2-8)$ and temperature $\left(20-80^{\circ} \mathrm{C}\right)$ were tested with $50 \mu \mathrm{M}$ ABTS in $0.1 \mathrm{M}$ citrate-phosphate-borate

conformational changes, that could cause higher $\mathrm{pH}-$ stability. Kunamneni et al. (2008) immobilised laccase from Myceliophthora thermophila by covalent binding with epoxy groups of polymethacrylate-based polymers and achieved similar results for optimal $\mathrm{pH}$.

\section{Optimum temperature and thermostability}

The effect of temperature on laccase activity of free and immobilised enzyme was determined in the range $20-80^{\circ} \mathrm{C}$ under standard conditions $(0.1 \mathrm{M}$ sodium acetate buffer, $\mathrm{pH} 5$ ). The optimum temperature was $60^{\circ} \mathrm{C}$ for free and immobilised laccase, but the latter showed a broader profile and its relative activity was $10 \%$ higher than the free laccase in the range $20-50^{\circ} \mathrm{C}$ (Fig. 1b).

Thermal stability was tested by incubating both laccases in $0.1 \mathrm{M}$ phosphate buffer ( $\mathrm{pH} 7)$ at selected temperatures: $20,40,50,60,70$ and $80^{\circ} \mathrm{C}$ for $24 \mathrm{~h}$. It was observed that the activity of the free laccase
(Fig. 2b) dropped more rapidly than that of immobilised laccase (Fig. 2d). After incubation at $80^{\circ} \mathrm{C}$ for $2 \mathrm{~h}$, free laccase was completely inactivated. However, immobilised laccase retained $50 \%$ of its initial activity after $2 \mathrm{~h}$, and $10 \%$ after $24 \mathrm{~h}$. Similar results were achieved by incubating both laccases at 60 and $70^{\circ} \mathrm{C}$. Both free and immobilised enzyme retained 100 and $70 \%$ of initial activity after $24 \mathrm{~h}$ incubation at 20 and $40^{\circ} \mathrm{C}$, respectively. These results agreed with the study carried out by Osma et al. (2010), who reported that the immobilisation affects the conformational flexibility of the enzyme since it causes an increase in enzyme rigidity and stability towards denaturation by high temperatures. The improvement on stability attained in the present study was similar to that achieved in previous investigations. Kunamneni et al. (2008) and Forde et al. (2010), who carried out the immobilisation of the Myceliophthora thermophila laccase on Sepabeads EC-EP3 and Dilbeads NK polymers and on mesoporous silicates particles, attained an enhancement of 10-15\% after immobilisation for the tested temperature range.

\section{Stability against chemical inactivation}

The stability of the immobilised and free enzymes against different inactivating agents was tested to anticipate their behaviour in applications where such conditions may be present, such as real effluents with variable composition of inhibitors, such as azides, chloride salts and organic solvents. The residual activity of both laccases after incubation with several chemical agents $\left(\mathrm{NaN}_{3}, \mathrm{ZnCl}_{2}, \mathrm{CoCl}_{2}, \mathrm{CaCl}_{2}\right.$, methanol, acetone) after $30 \mathrm{~min}$ was measured.

It was observed that laccase immobilised on Eupergit $\mathrm{C} 250 \mathrm{~L}$ had only a slightly higher stability (2-3\%) than free laccase against $\mathrm{ZnCl}_{2}, \mathrm{CoCl}_{2}, \mathrm{CaCl}_{2}$ salts (residual activity from $40-45$ to $41-46 \%$ ). This was probably due to the small dimension of the ions that allowed them to easily migrate into the structure of the biocatalyst and inactivate laccase to a similar extent (Cabana et al. 2007). The improvement of the stability against organic solvents by immobilisation was more significant (the residual activity in methanol varied from 41.6 to $55.9 \%$ and acetone from 40.4 to $46.3 \%$ between free and immobilised laccase, respectively). A stronger effect was observed in the presence of $\mathrm{NaN}_{3}$. In this case, the immobilised laccase displayed a residual activity twice as high as the free 
Fig. $2 \mathrm{pH}(\mathbf{a}, \mathbf{c})$ and thermal (b, d) stability profiles of free laccase (a, b) and immobilised laccase on Eupergit C 250L (c, d), respectively. $\mathrm{pH}$ values tested: 2 (filled black circle), 4 (square), 6 (Times symbol) and 8 (asterisk);

Temperatures tested: $20^{\circ} \mathrm{C}($ filled triangle $)$, $40^{\circ} \mathrm{C}$ (filled diamond $), 50^{\circ} \mathrm{C}$ (filled circle), $60^{\circ} \mathrm{C}$ (square), $70^{\circ} \mathrm{C}$ (Times symbol) and $80^{\circ} \mathrm{C}$ (asterisk)
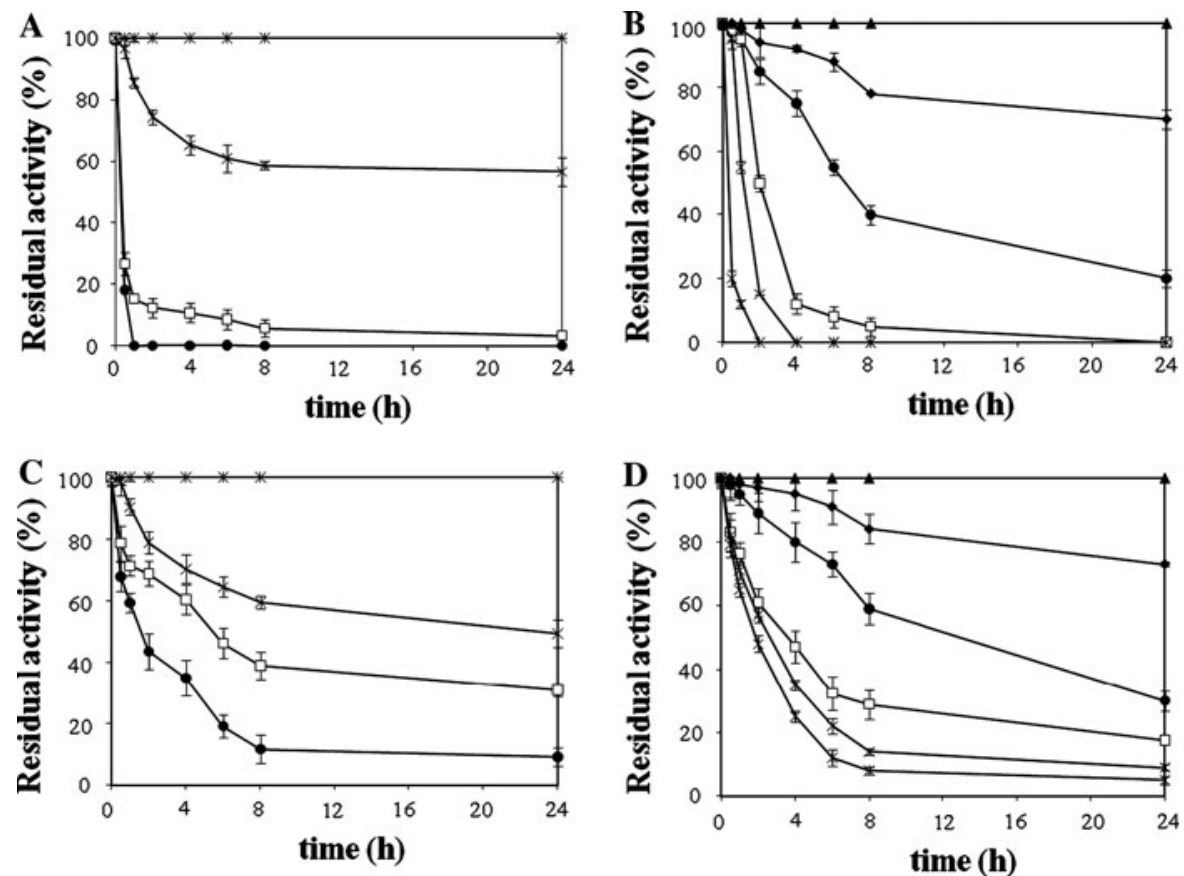

laccase activity (31.9 and 15.1\%). Similar conclusions were attained with Coriolopsis polyzona laccase immobilised through the formation of cross-linked aggregates (Cabana et al. 2007) and covalently immobilised on Celite R-33 support (Cabana et al. 2009) and with Trametes pubescens laccase immobilised on alumina pellets (Osma et al. 2010).

\section{Determination of apparent kinetic parameters}

Michaelis-Menten kinetic parameters of free and immobilised laccase were obtained by using ABTS as the substrate. The value of $\mathrm{K}_{\mathrm{M}}$ for the immobilised laccase $(150 \pm 10 \mu \mathrm{mol} / \mathrm{l})$ was approximately 3 -fold higher than that of the free enzyme $(56 \pm 2 \mu \mathrm{mol} / \mathrm{l})$, and $v_{\max }$ of the immobilised enzyme was 5-fold lower $(693 \pm 13$ and $3330 \pm 42 \mu \mathrm{mol} / \mathrm{min}$ 1, respectively). The efficiency of the immobilised laccase $(2.75 \pm$ $0.051 / \mu \mathrm{mol} \mathrm{min})$, based on the ratio between the turnover number and the Michaelis constant $\left(\mathrm{k}_{\mathrm{cat}} / \mathrm{K}_{\mathrm{M}}\right)$, was approximately twice as low as that of the free enzyme $(6.01 \pm 0.40 \mathrm{l} / \mu \mathrm{mol} \mathrm{min})$. Lower efficiencies for immobilised laccase and catalase from Lentinus edodes on Eupergit $\mathrm{C}$ were also reported by D'Annibale et al. (2000) and Alptekin et al. (2010), respectively. Several authors have suggested that this effect could be related to diffusion substrate limitations, substrate partitioning, lower accessibility of the substrate to the active site, protein conformational changes, internal mass transport constraint and/or substrate/product adsorption onto the carrier surface (Davis and Burns 1992; Hernaiz and Crout 2000; Rekuc et al. 2010; Yamak et al. 2009).

\section{Reusability of the immobilised laccase}

The reusability of the immobilised laccase was also evaluated under an efficiency perspective. The enzyme was incubated with ABTS in a $0.1 \mathrm{M}$ phosphate buffer $(\mathrm{pH} 7)$ at room temperature, for 10 cycles of $5 \mathrm{~h}$. As expected, the activity of the immobilised enzyme fell steadily as the number of cycles increased (Fig. 3). However, immobilised laccase retained $65 \%$ of initial activity after 10 batches. In literature, laccase immobilised on activated poly(vinyl alcohol) retained $60 \%$ of the initial activity values after 10 cycles (Yingui et al. 2002), while laccase immobilised on amineterminated magnetic nanocomposites, $80 \%$ after five consecutive operations (Xiao et al. 2006).

\section{Storage stability}

Free and immobilised laccases were stored at $4^{\circ} \mathrm{C}$ and at room temperature, with periodical sampling and monitoring. After 3 months, the residual activity of both free and immobilised laccase stored at $4{ }^{\circ} \mathrm{C}$ was 


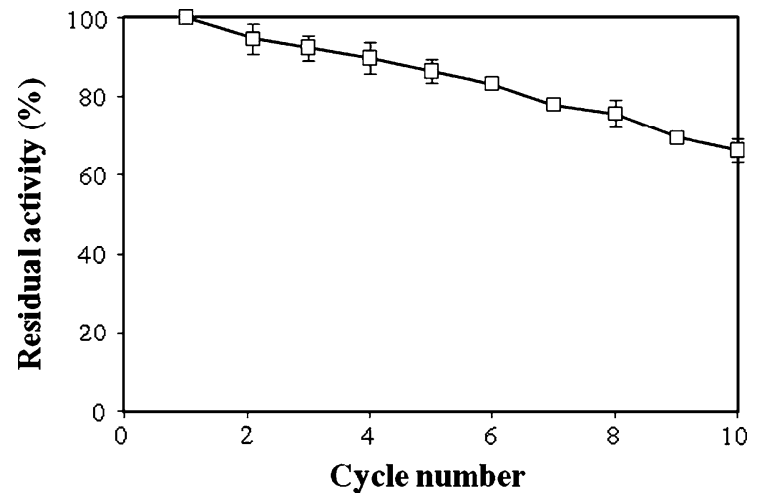

Fig. 3 Residual activity (\%) of immobilised laccase on Eupergit $\mathrm{C} 250 \mathrm{~L}$ after cycles $(5 \mathrm{~h})$ of $50 \mu \mathrm{M}$ ABTS oxidation in batch reaction

around $98 \%$. However, at room temperature, the residual activity of free laccase amounted to $95 \%$, while immobilised laccase maintained significant activity with a negligible loss of activity (1.5\%) after 1 month and only $0.5 \%$ additional after 2 months. In previous research, covalently immobilised laccase from Myceliophthora thermophila on Sepabeads ECEP3 carriers retained $96 \%$ of its initial activity after storage at $4^{\circ} \mathrm{C}$ for 4 months (Kunamneni et al. 2008). Alptekin et al. (2010) reported residual activities of immobilised catalase on Eupergit $\mathrm{C}$ of 68 and $79 \%$ after storage for 28 days at $5^{\circ} \mathrm{C}$ and room temperature, respectively.

Decolourisation of a model synthetic dye by immobilised laccase

With the aim of testing the feasibility of the immobilised laccase in a packed bed reactor (PBR), the biocatalyst was used for the continuous elimination of the dye AG27 as a model substrate. The reactor was operated continuously for short periods of $4 \mathrm{~h}$ until steady-state conditions were achieved.

As shown in Fig. 4, the percentage of dye removal significantly decreased after each operation with the corresponding decrease of the adsorption of the dye on the support. The extent of this combined removal was well conserved over the treatment cycles, achieving high degrees of elimination: 88, 79, 69 and 57\% for the different cycles. The levels of removal related to adsorption of AG27 on the support varied from 18 to $6 \%$ between the first and the fourth cycle. Under these circumstances, the operation time of the reactor might

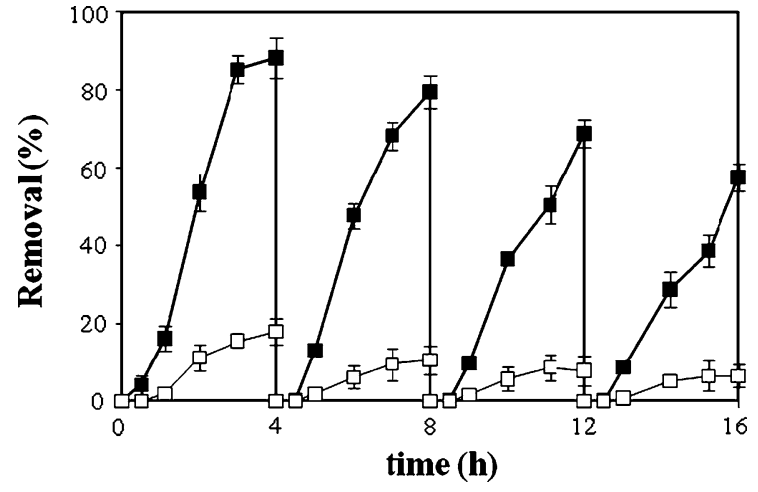

Fig. 4 Removal of AG27 dye by immobilised laccase (10 g biocatalyst, $9.7 \mathrm{U} / \mathrm{g}$ ) in a continuous PBR operated in consecutive cycles, at room temperature and $\mathrm{pH}$ 7. The open symbols represent the removal accounted by the adsorption of the AG27 dye on the support with inactivated laccase. Measures were carried out by duplicate, standard deviations are shown

be increased in order to assure high levels of dye removal. This decrease on the removal percentages may be related to an enzyme inactivation produced by operational conditions, diffusion problems caused by dye or products adsorption onto the carrier surface and the potential clogging phenomena caused by insoluble products formed (Hernaiz and Crout 2000; Rekuc et al. 2010). In order to verify that assumption, the residual activity after the fourth cycle was determined after washing the biocatalyst with $0.1 \mathrm{M}$ phosphate buffer ( $\mathrm{pH} 7$ ). It was observed an inactivation of $24 \%$ (residual activity $76 \%$ ).

Enzymatic effect was observed as the major contribution in the removal of the dye. In addition, negligible leaching of the immobilised enzyme was detected. Thus, immobilised laccase on Eupergit C 250L showed high efficiency in the enzymatic oxidation of AG27 dye and the reusability of the proposed catalyst was confirmed, which is of remarkable interest regarding the potential use of immobilised laccase, in spite of the decreasing in the decolourisation efficiency over the consecutive cycles.

This high efficiency and reusability of immobilised laccase on the oxidation of the anthraquinonic dye used was reported by Kunamneni et al. (2008) with Myceliophthotra thermophila laccase immobilised on Sepabeads EC-EP3 carriers in a PBR, although the physical adsorption on the support was not taken into account. On the contrary, Zille et al. (2003) reported that the decolourisation of Reactive black 5 dye, an azo dye, by laccase immobilised on silica beads was 
due to adsorption (79\%) and a minor amount (4\%) to enzymatic activity. Soares et al. (2001) also demonstrated the removal of an anthraquinonic dye (Remazol Brilliant Blue R) by a free commercial laccase formulation, but in the presence of the mediator HBT and a non-ionic surfactant.

Elimination of endocrine disrupting chemicals (EDCs) by immobilised laccase

The packed bed reactor with the solid biocatalyst was also used for the removal of three EDCs from an aqueous solution of $5 \mathrm{mg} / \mathrm{l}$ of each compound. The results of enzymatic and adsorption-based removal of the selected estrogens are shown in Fig. 5. The maximum elimination of E1 $(65 \%)$ was attained after $4 \mathrm{~h}$ of operation time (Fig. 5a). However, after a short period ( $2 \mathrm{~h})$ the steady state removal of E2 and EE2 was achieved (Fig. 5b, c respectively). This higher affinity for E2 and EE2 was also observed with free enzyme in batch experiments, although higher levels of degradation were attained by free laccase (Lloret et al. 2010). The degrees of elimination due to adsorption to the support with inactivated laccase were approximately $22 \%$ for E2, less than $20 \%$ for EE2 and $11 \%$ for E1. The adsorption seemed to be correlated with the hydrophobicity of each chemical. The highest adsorption was seen for E2, which has the highest octanol-water partition coefficient $\left(\log \mathrm{k}_{\mathrm{ow}}\right.$ $3.9-4.0)$ and the lowest solubility $(3.6 \mathrm{mg} / \mathrm{l})$. The slightly $\log \mathrm{k}_{\mathrm{ow}}$ and water solubility of EE2 are 2.8-4.2 and $11.3 \mathrm{mg} / \mathrm{ml}$ and of E1 3.1-3.4 and $30 \mathrm{mg} / \mathrm{l}$ (Suarez et al. 2008). Even if part of the elimination observed was associated with the adsorption of these chemicals on the support, the enzymatic action was clear in the removal of these EDCs (represented $80 \%$ of the total removal). This oxidative ability may open the possibility of using Myceliophthora thermophila laccase immobilised on Eupergit C 250L support to treat effluents containing this kind of estrogenic compounds. Additionally, the biocatalyst retained $84 \%$ of its initial activity after the treatment and negligible leaching of the immobilised enzyme was detected during the operation. Similar results were reported by Cabana et al. (2009) during the elimination of $5 \mathrm{mg} / \mathrm{l}$ of nonylphenol, bisphenol $\mathrm{A}$ and triclosan in a PBR by laccase covalently immobilised on Celite R-633 supports. The adsorption of those compounds on the support with inactivated laccase
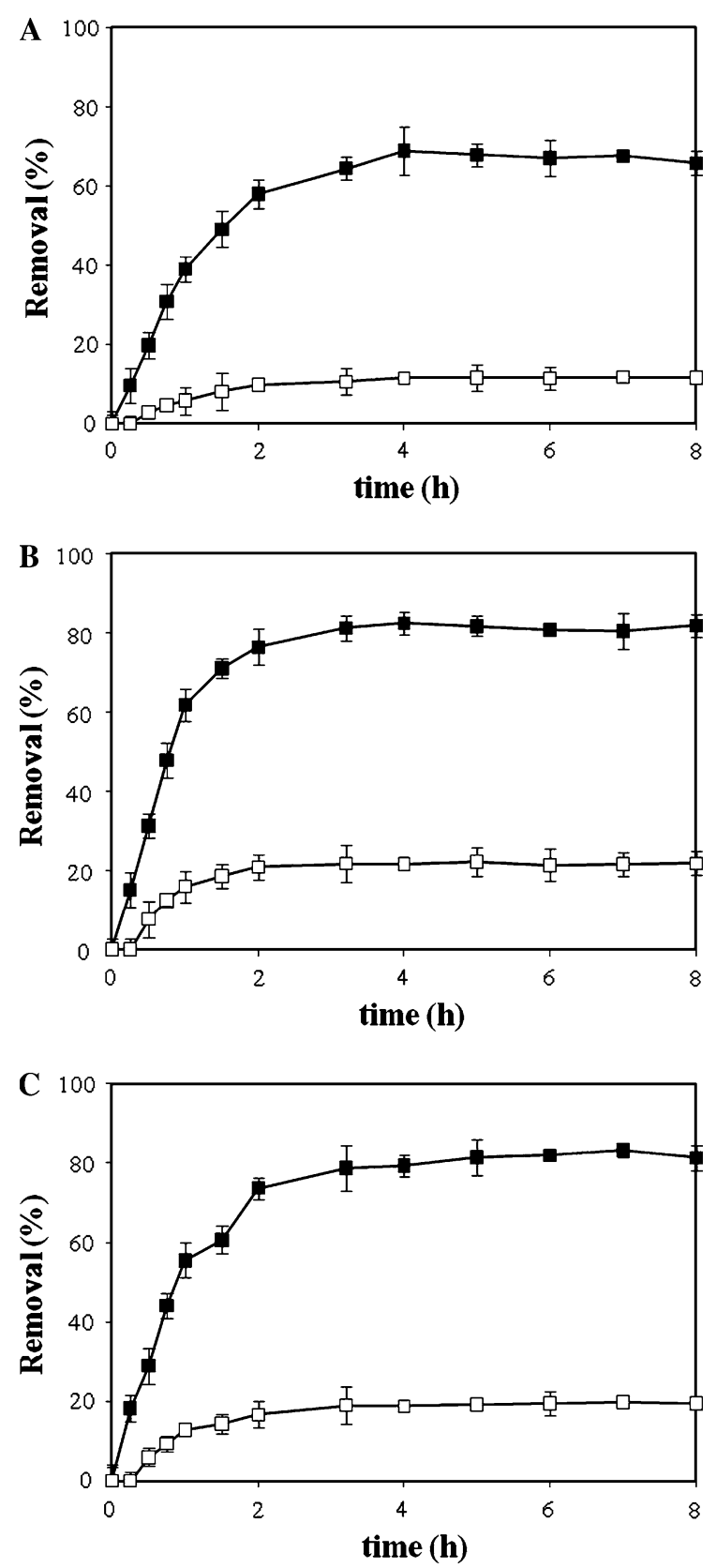

Fig. 5 Removal of E1 (a), E2 (b) and EE2 (c) by immobilised laccase (10 g biocatalyst, $9.7 \mathrm{U} / \mathrm{g}$ ) in a continuous PBR at room temperature and $\mathrm{pH}$ 7. The open symbols represent the removal accounted by the adsorption of the EDCs on the support with inactivated laccase. Measures were carried out by duplicate, standard deviations are shown

varied from 40 to $60 \%$ and this physical removal was also linked to the solubility and hydrophobicity of the different EDCs. Russo et al. (2008) also observed the adsorption of an anthraquinone-dye on Eupergit 
supports with immobilised laccase. These authors reported two different steps: during the first step, dye adsorption on the carrier was extensive and enzymatic conversion was negligible; during the second step and under steady state conditions, the removal of the dye was attributed to enzymatic conversion and an adsorption/desorption equilibrium was attained. According to the results presented in Fig. 5, a similar interaction between the EDCs and the Eupergit support could take place. Furthermore, adsorption is expected to be a determining factor during the elimination of estrogens at lower concentrations (from $\mu \mathrm{g} / \mathrm{l}$ to $\mathrm{ng} / \mathrm{l}$ ), as reported by previous studies. For instance, Carballa et al. (2004) observed a removal of $20 \%$ of E2 in the primary treatment of a Spanish STP, whereas in a German STP, EE2 and E2 were eliminated up to 35 and 29\%, respectively (Andersen et al. 2003). Snyder et al. (2007) reported higher adsorption percentages $(75,78$ and $85 \%$ for E1, EE2 and E2, respectively), on activated carbon. However, the main advantage of the processes presented in the current work is that estrogens were eliminated mainly by enzymatic transformation. Therefore, the compounds were transformed and their estrogenic activity reduced.

Several previous studies reported high levels of enzymatic oxidation of these compounds with free enzyme. For example, Tanaka et al. (2001) degraded EE2 by $90 \%$ within $48 \mathrm{~h}$ using $0.8 \mathrm{U} / \mathrm{ml}$ of laccase from Trametes sp. and Pycnoporus coccineus. Auriol et al. (2008) degraded completely E1, EE2 and E2 after $1 \mathrm{~h}$-treatment using $20 \mathrm{U} / \mathrm{l}$ and Suzuki et al. (2003) transformed E2 and EE2 by $100 \%$ in $1 \mathrm{~h}$ by the laccase-HBT system. In addition, our research group (Lloret et al. 2010) has recently used free Myceliophthora thermophila laccase for the elimination of these compounds, with a higher efficiency (total removal of E2 was attained in only $2 \mathrm{~h}$, with less initial laccase activity and no mediator was used). In the current study, we propose the immobilisation of laccase into Eupergit supports for EDCs removal. Immobilisation is probably the best way to attain enzyme stabilisation, since it provides increasing operational stability, easy of separation and catalyst reuse (Kunamneni et al. 2008; Osma et al. 2010). Moreover, the main advantage of the immobilisation of laccase on Eupergit supports is the extremely easy technique procedure, comprising mixing of the components, incubation and washing of the product. The continuous elimination of
EDCs by immobilised laccase has been reported for bisphenol A using laccase carried on nylon membrane (Diano et al. 2007) and covalently bound onto alkylaminated controlled porosity glass (Iida et al. 2002). Cabana et al. $(2007,2009)$ tested the elimination of bisphenol A, triclosan and nonylphenol by laccase immobilised through the formation of crosslinked enzyme aggregates and on support Celite R-633. In our study, E1, E2 and EE2 were degraded for the first time by Myceliophthora thermophila laccase immobilised on Eupergit C 250L support. However, the use of PBRs with immobilised enzymes could present some disadvantages such as: passive or poor aeration, slow mass transfer, the high pressure drop in the bed can provoke its compactation and hence biocatalyst damage, the possible formation of insoluble products which would lead to clogging phenomena, limitation in substrate's diffusion, intra particle diffusion limitations on reaction rates and possible leakage of the biocatalyst from the support (Gómez et al. 2007; Murry et al. 2002; O'Neill et al. 1971; Osma et al. 2010; Rekuc et al. 2009). Additionally, long-term operation of packed bed reactor is still a challenge. The drawback is the requirement for periodical regeneration of the biocatalyst by some cleaning solution (Watanabe et al. 2001).

Although the main objective was not to determine degradation products, an important effort has been devoted to the identification of products. Unfortunately, we have not identified any reaction products by the HPLC protocol used, suggesting that a polymerisation reaction could have occurred or that the products reacted with either the laccase or the carrier. However, regarding the toxicity of estrogens treated by laccase, several reports have shown that the removal of estrogenic activity was correlated with the removal of the parent compound, indicating that the products of the degradation exhibited lower or no estrogenic activity (Auriol et al. 2008). The estrogenic activity of the effluent of the continuous reactor was determined by the LYES assay. A decrease of $79 \%$ was measured in the enzymatic reactor while only $14 \%$ corresponded to inactivated laccase.

\section{Conclusions}

Myceliophthora thermophila laccase was covalently immobilised to Eupergit C 250L support. Although the 
immobilised biocatalyst displayed a lower substrate affinity than the free enzyme, the immobilisation improved enzyme stability for storage, $\mathrm{pH}$, and temperature, as well as in the presence of different inactivating chemicals. It was also shown that immobilised laccase on Eupergit C 250L achieved high decolourisation of Acid Green 27 by enzymatic degradation and reusability. These important properties of immobilised laccase could be a potential advantage for various biotechnological and industrial applications. In addition, immobilised laccase on a solid support was applied for the first time for the continuous elimination of the EDCs E1, E2, and EE2 in a PBR. Overall, our results showed that laccase immobilised on Eupergit $\mathrm{C} 250 \mathrm{~L}$ is a promising tool to increase the applicability of laccase in bioremediation processes.

Acknowledgments This study has been supported by the Spanish project CTQ2010-20258 and the European project EUI2008-03703. L. Lloret thanks the Spanish Ministry of Education for the FPU grant AP2008-01954. Gemma Eibes thanks the Xunta de Galicia for an Angeles Alvariño contract.

\section{References}

Alptekin O, Tukel SS, Yildirim D, Alagoz D (2010) Immobilization of catalase onto eupergit $\mathrm{C}$ and its characterization. J Mol Catal B Enzym 64:177-183

Andersen H, Siegrist H, Halling-Sonrensen B, Ternes TA (2003) Fate of estrogens in a municipal sewage treatment plant. Environ Sci Technol 37:4021-4026

Auriol M, Filali-Meknassi Y, Tyagi RD, Adams CD, Surrampali RY (2006) Endocrine disrupting compounds removal from wastewater, a new challenge. Process Biochem 41:25-539

Auriol M, Filali-Meknassi Y, Adams CD, Tyagi RD, Noguerol TN, Piña B (2008) Removal of estrogenic activity of natural and synthetic hormones from a municipal wastewater: efficiency of horseradish peroxidase and laccase from Trametes versicolor. Chemosphere 70:445-452

Berrio J, Plou FJ, Ballesteros A, Martínez AT, Martínez MJ (2007) Immobilization of Pycnoporus coccineus laccase on Eupergit C: stabilization and treatment of olive oil mil wastewaters. Biocatal Biotransform 25:130-134

Blánquez P, Guieysse B (2008) Continuous biodegradation of $17 \beta$-estradiol and $17 \alpha$-ethinylestradiol by Trametes versicolor. J Hazard Mater 150:459-462

Cabana H, Jones JP, Agathos SN (2007) Preparation and characterization of cross-linked laccase aggregates and their application to the elimination of endocrine disrupting chemicals. J Biotechnol 132:23-31

Cabana H, Alexandre C, Agathos SN, Jones JP (2009) Immobilization of laccase from the white rot fungus Coriolopsis polyzona and use of the immobilized biocatalyst for the continuous elimination of endocrine disrupting chemicals. Bioresour Technol 100:3447-3458
Camarero S, Ibarra D, Martínez AT, Romero J, Gutiérrez A, del Río JC (2007) Paper pulp delignification using laccase and natural mediators. Enzyme Microb Technol 40:1264-1271

Carballa M, Omil F, Lema JM, Llompart M, Garcia-Jares C, Rodriguez I, Gomez M, Ternes T (2004) Behavior of pharmaceuticals, cosmetics and hormones in a sewage treatment plant. Water Res 38:2918-2926

Carballa M, Omil F, Lema JM (2005) Removal of cosmetic ingredients and pharmaceuticals in sewage primary treatment. Water Res 39:4790-4796

D’Annibale A, Stazi SR, Vinciquerra V, Sermanni GG (2000) Oxirane-immobilized Lentinula edodes laccase: stability and phenolics removal efficiency in olive mill wastewater. J Biotechnol 77:265-273

Davis S, Burns R (1992) Covalent immobilization of laccase on activated carbon for phenolic effluent treatment. Appl Microbiol Biotechnol 37:474-479

Diano N, Grano V, Francote L, Caputo P, Ricupito A, Attanasio A, Bianco M, Bencivenga U, Rossi S, Manco I, Mita L, Del Pozo G, Mita DG (2007) Non-isothermal bioreactors in enzymatic remediation of waters polluted by endocrine disruptors: BPA as a model of pollutant. Appl Catal B Environ 69:252-261

Durán N, Esposito E (2000) Potential applications of oxidative enzymes and phenoloxidase-like compounds in wastewater and soil treatment: a review. Appl Catal B Environ 28: 83-99

Durán N, Rosa MA, D’Annibale A, Gianfreda L (2002) Applications of laccases and tyrosines (phenoloxidases) immobilized on different supports: a review. Enzyme Microb Technol 31:907-931

Esplugas S, Bila DM, Krause LGT, Dezotti M (2007) Ozonation and advanced oxidation technologies to remove endocrine disrupting chemicals (EDCs) and pharmaceuticals and personal care products (PPCPs) in water effluents. J Hazard Mater 149:631-642

Forde J, Tully E, Vakurov A, Gibson TD, Millner P, Ó’Fágáin C (2010) Chemical modification and immobilisation of laccase from Trametes hirsuta and from Myceliophthora thermophila. Enzyme Microb Technol 46:430-437

Gómez de Segura A, Alcalde M, Yates M, Rojas-Cervantes ML, López-Cortés N, Ballesteros A, Plou FJ (2004) Immobilization of dextransucrase from Leuconostoc mesenteroides NRRLB512F on Eupergit C supports. Biotechnol Prog 20:1414-1420

Gómez JL, Bódalo A, Gómez E, Hidalgo AM, Gómez M, Murcia MD (2007) Experimental behaviour and design model of a fluidized bed reactor with immobilized peroxidase for phenol removal. Chem Eng J 127:47-57

Hanefeld U, Gardossi L, Magner E (2009) Understanding enzyme immobilisation. Chem Soc Rev 38:453-468

Hernaiz MJ, Crout DHG (2000) Immobilization/stabilization on Eupergit $\mathrm{C}$ of the $\beta$-galactosidase from $B$. circulans and a $\alpha$-galactosidase from Aspergillus oryzae. Enzyme Microb Technol 27:26-32

Hublik G, Schinner F (2000) Characterization and immobilization of the laccase from Pleurotus ostreatus and its use for the continuous elimination of phenolic pollutants. Enzyme Microb Technol 27:330-336

Iida Y, Kikuchi T, Morii T, Satoh I (2002) Bioconversion of bisphenol A by immobilized laccase column in combination with an electrolytic devide. Chem Sensors 18:127-129 
Illanes A (1999) Stability of biocatalysts. Electron J Biotechnol 2:1-9

Joss A, Zabczynski S, Göbel A, Hoffmann B, Löffler D, McArdell CS, Ternes TA, Thomsen A, Siegrist H (2006) Biological degradation of pharmaceuticals in municipal wastewater treatment: proposing a classification scheme. Water Res 40:1686-1696

Katchalski-Katzir E, Kraemer DM (2000) Eupergit C, a carrier for immobilization of enzymes of industrial potential. J Mol Catal B Enzym 10:157-176

Kim YJ, Nicell JA (2006) Impact of reaction conditions on the laccase-catalyzed conversion of bisphenol A. Bioresour Technol 97:1431-1442

Knezevic Z, Milosavic N, Bezbradica D, Jakovljevic Z, Prodanovic R (2006) Immobilization of lipase from Candida rugosa on Eupergit C supports by covalent attachment. Biochem Eng J 30:269-278

Kraemer DM, Pennewiss H, Plainer H, Schee R, Schleier W (1985) Roehm, United States Patent 4511694

Kunamneni A, Ghazi I, Camarero S, Ballesteros A, Plou FJ, Alcalde M (2008) Decolorization of synthetic dyes by laccase immobilized on epoxy-activated carriers. Process Biochem 43:169-178

Leusch FDL, Chaoman HF, Korner W, Gooneratne SR, Tremblay LA (2005) Efficacy of an advanced sewage treatment plant in southeast Queensland, Australia, to remove estrogenic chemicals. Environ Sci Technol 39:5781-5786

Li L, Zhu Y, Huang Z, Jiang Z, Chen W (2007) Immobilization of the recombinant xylanase $\mathrm{B}$ (XynB) from the hyperthermophilic Thermotoga maritima on metal-chelate Eupergit C 250L. Enzyme Microb Technol 41:278-285

Lloret L, Eibes G, Lú-Chau TA, Moreira MT, Feijoo G, Lema JM (2010) Laccase-catalyzed degradation of anti-inflammatories and estrogens. Biochem Eng J 51:124-131

Murry VR, Bhat J, Muniswaran PKA (2002) Hydrolysis of oils by using immobilized lipase enzyme: a review. Biotechnol Bioprocess Eng 7:57-66

Nicotra S, Intra A, Ottolina G, Riva S, Danieli B (2004) Laccase-mediated oxidation of the steroid hormone $17 \beta$ estradiol in organic solvents. Tetrahedron Asymmetr 15:2927-2931

O’Neill SP, Dunnill P, Lilly MD (1971) A comparative study of immobilized amyloglucosidase in a packed bed reactor and a continuous feed stirred tank reactor. Biotechnol Bioeng $13: 337-352$

Osma JF, Toca-Herrera JL, Rodríguez-Couto S (2010) Biodegradation of a simulated textile effluent by immobilisedcoated laccase in laboratory-scale reactors. Appl Catal A Gen 373:147-153

Rekuc A, Jastrzembska B, Liesiene J, Bryjak J (2009) Comparative studies on immobilized laccase behavior in packedbed and batch reactors. J Mol Catal B Enzym 57:216-223

Rekuc A, Bryjak J, Szymanska K, Jarzebski AB (2010) Very stable silica-gel-bound laccase biocatalysis for the selective oxidation in continuous systems. Bioresour Technol 101:2076-2083

Russo ME, Giardina P, Marzocchella A, Salatino P, Sannia G (2008) Assessment of anthraquinone-dye conversion by free and immobilized crude laccase mixtures. Enzyme Microb Technol 42:521-530
Schultis T, Metzger JW (2004) Determination of estrogenic activity by LYES-assay (yeast estrogen screen-assay assisted by enzymatic digestion with lyticase). Chemosphere 57:1649-1655

Sei K, Takeda T, Soda SO, Fujita M, Ike M (2008) Removal characteristics of endocrine-disrupting chemicals by laccase from white-rot fungi. J Environ Sci Health Part A 43:53-60

Snyder SA, Adham S, Redding AM, Cannon FS, DeCarolis J, Oppenheimer J, Wert EC, Yoon Y (2007) Role of membranes and activated carbon in the removal of endocrine disruptors and pharmaceuticals. Desalination 202:156-181

Soares GMB, Costa-Ferreira M, Pessoa de Amorin MT (2001) Decolorization of an anthraquinone-type dye using a laccase formulation. Bioresour Technol 79:171-177

Suarez S, Carballa M, Omil F, Lema JM (2008) How are pharmaceuticals and personal care products (PPCPs) removed from urban wastewaters? Environ Sci Biotechnol $7: 125-138$

Suzuki K, Hiraia H, Muratab H, Nishida T (2003) Removal of estrogenic activities of $17 \beta$-estradiol and ethinylestradiol by ligninolytic enzymes from white rot fungi. Water Res 37:1972-1975

Taboada-Puig R, Junghanns C, Demarche P, Moreira MT, Feijoo G, Lema JM, Agathos SN (2011) Combined crosslinked aggregates from versatile peroxidase and glucose oxidase: production, partial characterization and application for the elimination of endocrine disruptors. Bioresour Technol 102:6593-6599

Tamagawa Y, Yamaki R, Hirai H, Kawai S, Nishida T (2006) Removal of estrogenic activity of natural steroidal hormone estrone by ligninolytic enzymes from white rot fungi. Chemosphere 65:97-101

Tanaka T, Tonosaki T, Nose M, Tomidokoro N, Kadomura N, Fujii T, Taniguchi M (2001) Treatment of model soils contaminated with phenolic endocrine-disrupting chemicals with laccase from Trametes sp. in a rotating reactor. J Biosci Bioeng 92:312-316

Ternes TA, Krechel P, Muller J (1999) Behavior and occurrence of estrogens in municipal sewage treatment plants-II. Aerobic batch experiments with activated sludge. Sci Total Environ 225:91-99

Tsutsumi Y, Haneda T, Nishida T (2001) Removal of estrogenic activities of bisphenol $\mathrm{A}$ and nonylphenol by oxidative enzymes from lignin-degrading basidiomycetes. Chemosphere 42:271-276

Watanabe Y, Shimada Y, Sugihara A, Tominaga Y (2001) Enzymatic conversion of waste edible oil to biodiesel fuel in a fixed-bed bioreactor. J Am Oil Chem Soc 78:703-707

Wesenberg D, Kyriakides I, Agathos SN (2003) White-rot fungi and their enzymes for the treatment of industrial dye effluents. Biotechnol Advan 22:161-187

Xiao H, Huang J, Liu C, Jiang D (2006) Immobilization of laccase on amine-terminated magnetic nano-composite by glutaraldehyde crosslinking method. Trans Nonferrous Metal Soc 16:414-418

Yamak O, Kalkan NA, Aksoy S, Altinok H, Hasirci N (2009) Semi-interpenetrating polymer networks (semi-IPNs) for entrapment of laccase and their use in Acid Orange 52 decolorization. Process Biochem 44:440-445 
Yingui D, Qiuling W, Shiyu F (2002) Laccase stabilization by covalent binding immobilization on activated polyvinyl alcohol carrier. Lett Appl Microbiol 35:451-456
Zille A, Tzanov T, Gubitz GM, Cavaco-Paulo A (2003) Immobilized laccase for the decolorization of Reactive black 5 dyeing effluent. Biotechnol Lett 25:1473-1477 